\title{
Antibodies against rabies virus in dogs with and without history of vaccination in Santa Maria - RS - Brazil
}

\author{
Karina Gonzalez Fernandes ${ }^{1}$ Mathias Martins ${ }^{1}$ Bruna Portolan Amaral ${ }^{1}$ \\ Juliana Felipetto Cargnelutti ${ }^{1}$ Rudi Weiblen ${ }^{2}$ Eduardo Furtado Flores ${ }^{2 *}$
}

\begin{abstract}
'Programa de Pós-graduação em Medicina Veterinária, Setor de Virologia, Universidade Federal de Santa Maria (UFSM), Av. Roraima, 1000, 97105-900, Santa Maria, RS, Brasil.

${ }^{2}$ Setor de Virologia , Departamento de Medicina Veterinária Preventiva, Universidade Federal de Santa Maria (UFSM), Santa Maria, RS, Brasil. E-mail: eduardofurtadoflores@gmail.com. *Corresponding author.

ABSTRACT: The present study investigated the frequency and magnitude of neutralizing antibodies to rabies virus (RABV) in dogs with and without historic of vaccination in Santa Maria/RS. Group A included serum samples from 440 dogs with recent historic of vaccination against rabies, obtained during the 2015 rabies vaccination campaign. Group B included 300 serum samples from dogs submitted to the Veterinary Hospital of the Universidade Federal de Santa Maria in 2015, whose historic of rabies vaccination was unknown. Serum samples were submitted to the rapid fuorescent focus inhibition test (RFFIT) to detect neutralizing antibodies against RABV. In group A, 70.6\% (310/440) of the samples had neutralizing antibody titers $\geq 0.5$ international units per milliliter (IU mL $L^{-1}$ ), considered an indicative of protection against rabies by the World Health Organization. However, approximately 30\% of the dogs did not contain antibodies in adequate levels. In group $B, 42.3 \%$ (127/300) of the samples contained neutralizing antibody titers $\geq 0.5 I U \mathrm{~mL}^{-1}$ and $57.7 \%(173 / 300)$ were negative or contained titers below of the value considered immunized. These results demonstrate that an important proportion of vaccinated dogs ( 30\%) did not develop adequate antibody levels, mainly those receiving a single vaccine dose. Serologic testing of animals with unknown historic of vaccination revealed relatively low vaccine coverage in the general dog population. Thus, reformulation of immunization strategies - especially the recommendation of a boost vaccination 30 days after the primary dose - and extension of vaccination campaigns are necessary to reach adequate levels and coverage of immunity against RABV in the canine population.
\end{abstract}

Key words: canine, immunity, $R A B V$, serological response, vaccine.

Anticorpos contra o vírus da raiva em cães com e sem histórico de vacinação em Santa Maria - RS - Brasil

RESUMO: O presente estudo investigou a frequência e a magnitude dos anticorpos neutralizantes do vírus da raiva (RABV) em cães com e sem histórico de vacinação em Santa Maria/RS. O Grupo A incluiu amostras de soro de 440 cães com histórico recente de vacinação contra a raiva, obtidos durante a campanha de vacinação contra a raiva de 2015. O Grupo B incluiu 300 amostras de cães submetidos ao Hospital Veterinário da Universidade Federal de Santa Maria em 2015, cujo histórico de vacinação antirrábica era desconhecido. As amostras de soro foram submetidas ao teste rápido de inibição de focos fluorescentes para detecção de anticorpos neutralizantes do RABV. No grupo A, 70,6\% (310/440) das amostras possuíam títulos de anticorpos neutralizantes $\geq 0,5$ unidades internacionais por mililitro (UI $\mathrm{mL}^{-1}$ ), considerado um indicador de proteção contra a raiva pela Organização Mundial da Saúde. No entanto, aproximadamente $30 \%$ dos animais não continham anticorpos em níveis adequados. No grupo B, 42,3\% (127/300) das amostras continham titulos de anticorpos neutralizantes $\geq 0,5 U I$ mL $L^{-1}$ e 57,7\% (173/300) eram negativas ou continham títulos abaixo do valor considerado imunizado. Estes resultados demonstram que uma proporção importante de cães vacinados ( 30\%) não desenvolveu níveis adequados de anticorpos, principalmente aqueles que receberam uma única dose de vacina. O teste sorológico de animais com histórico de vacinação desconhecido revelou uma cobertura vacinal relativamente baixa na população geral de cães. Assim, a reformulação das estratégias de imunização - especialmente a recomendação de uma vacinação de reforço 30 dias após a primeira dose - e a extensão das campanhas de vacinação são necessárias para atingir níveis e cobertura adequados de imunidade contra o RABV na população canina.

Palavras-chave: canino, imunidade, $R A B V$, resposta sorológica, vacina.

\section{INTRODUCTION}

Rabies is an ancient zoonotic disease that remains a serious problem for public and animal health in many countries (OIE, 2016). Every year, approximately 70.000 human deaths are attributed to rabies, mainly in developing countries (WHO, 2013). The disease is caused by rabies virus (RABV), an enveloped, bullet-shaped and negative-sense RNA virus belonging to the genus Lyssavirus, family Rhabdoviridae (ICTV, 2014). Virtually, all warmblooded animals (mammals) are susceptible to 
RABV infection, whose ensuing disease is usually fatal (RHODES et al., 1998).

In nature, RABV is perpetuated through cycles of infection involving carnivores and other terrestrial mammals (North America and Europe) or hematophagous bats (Central and South America). In South America, the hematophagous bats Desmodus rotundus are the main reservoirs and sources of RABV for livestock (ARELLANO-SOTA, 1988). In rural/ wild regions, human infection is usually associated with bytes/aggressions by bats or, less frequently, by terrestrial mammals (RHODES et al., 1998).

In urban areas, RABV is maintained through cycles of transmission among dogs, and less frequently, cats (RHODES et al., 1998). RABV has been occasionally detected in non-hematophagous bats in some cities, yet their role in virus transmission is unclear (CABRAL et al., 2012). Control of urban rabies is usually performed by massive immunization of canine and feline populations, associated with control of populations of stray dogs (WHO, 2013).

In many Brazilian states, urban rabies (e.g. canine and feline) has been controlled and eradicated during the last decades, mainly through official programs of immunization, which were able to reduce drastically virus circulation (SVS, 2016). However, the virtual eradication or significant decrease in the number of cases led to the gradual dismounting of the official immunization programs (WHO, 2013). Sporadic cases of canine and feline rabies have been occasionally reported in a few cities in the last years, indicating the need for continuing vaccination (SVS, 2016; SILVA et. al., 2015).

Few states and/or cities, mainly in Southeastern Brazil, maintain official rabies control programs by massive vaccination. In most of the country, annual immunization of dogs against rabies became a voluntary initiative or, in some cases, carried out by non-governmental organizations. These initiatives are not coordinated and usually do not follow strict guidelines regarding to immunization strategies and periodic evaluation (FLORES - verbal report).

In Rio Grande do Sul State (RS), an increase in the number of cases of bat/herbivorous rabies is occurring. Between 2011 and 2016, the official agency counted 538 outbreaks of rabies (SEAPA, 2016). In contrast, urban rabies is virtually eradicated with no canine cases and only two feline cases (a bat lineage RABV) in the last 20 years. However, the continuous circulation of RABV in bats and herbivorous in the last years has raised concerns about a possible transmission of the virus to urban dogs.
Located in central RS, Santa Maria has approximately 300 thousand inhabitants and the actual size of the canine population is unknown. In addition to voluntary vaccination in Veterinary Clinics and Pet Shops, whose numbers are difficult to estimate, an annual vaccination campaign has been carried out by veterinary students, reaching from 13.000 to 18.000 animals every year (FLORES - verbal report). Vaccine coverage and efficacy are largely unknown. Thus, this study aimed to determine the magnitude of the serological response in dogs with recent history of vaccination and to investigate the frequency and level of antibodies to RABV in dogs with unknown history of vaccination against rabies in Santa Maria/RS.

\section{MATERIALS AND METHODS}

\section{Serum samples}

Serum samples were collected from two groups of dogs: group A $(n=440)$ consisted of dogs taken to the annual rabies vaccination campaign (2015), with a confirmed history of at least one immunization against rabies from 2013 to 2015; group $\mathrm{B}(\mathrm{n}=300)$ consisted of dogs taken to the University Veterinary Hospital (HVU/UFSM) in 2015 for varied clinical and/or surgical procedures, whose history of vaccination against rabies was unknown. History of vaccination in animals of group A was ascertained by positive answer by the owner or presentation of vaccination certificate. In addition, data regarding to gender, age, and number of vaccinations and year of the last immunization were also obtained. Serum samples were stored at $-20^{\circ} \mathrm{C}$ and inactivated at $56^{\circ} \mathrm{C}$ for $30 \mathrm{~min}$ before testing.

\section{Cells and virus}

All procedures of virus amplification, quantitation and virus-neutralizing tests were performed in baby hamster kidney cells (BHK-21 $\left[\right.$ C-13 ATCC ${ }^{\circledR}$ CCL-10 $\left.{ }^{\mathrm{TM}}\right]$ ). Cells were cultured in minimum essential medium (MEM) containing ampicillin (1.6mg L $\left.\mathrm{L}^{-1}\right)$, streptomycin $\left(0.4 \mathrm{mg} \mathrm{L}^{-1}\right)$ and amphotericin B (2.25 $\left.\mathrm{mg} \mathrm{L}^{-1}\right)$ supplemented with $10 \%$ fetal bovine serum (FBS). The RABV strain Challenge Virus Standard (CVS132-11A) used in virus-neutralizing tests was kindly provided by the Instituto Pasteur (São Paulo, SP, Brazil).

\section{Rapid fluorescent focus inhibition test (RFFIT)}

Tests were performed in 96-well plates according to SMITH et al. (1973), with modifications. Briefly, two-fold dilutions of sera (starting at 1:10) were incubated with approximately 100 tissue 
culture infectious dose $50 \%\left(\mathrm{TCID}_{50}\right)$ of CVS for $90 \mathrm{~min}$ at $37^{\circ} \mathrm{C}$, followed by addition of a suspension of BHK-21 (approximately $2.5 \times 10^{4}$ cells/well), culture medium and incubation at $37^{\circ} \mathrm{C}$ in $5 \% \mathrm{CO}_{2}$ for $48 \mathrm{~h}$. Then, cells were individualized by trypsin, resuspended in culture medium and left to attach in multispot glass slides. Cells were then fixed in cold acetone for $5 \mathrm{~min}$, air dried and incubated with an anti-RABV antibody conjugated with fluorescein isothiocyanate (FITC) for $1 \mathrm{~h}$. Slides were observed in an epifluorescence microscope (Axiolab ZEISS ${ }^{\circledR}$ ). All tests were performed in duplicates. Neutralizing antibodies titer was considered the highest serum dilution able to prevent virus replication as ascertained by absence of virus antigens in indicator cells. A reference positive serum provided by Instituto Pasteur (São Paulo, SP, Brazil), containing 0.5 international units per milliliter (IU mL $\mathrm{mL}^{-1}$ ), was used in all tests. Neutralizing titer of this serum was used as reference to calculate the neutralizing titer of test samples in IU $\mathrm{mL}^{-1}$. Neutralizing titers were converted to geometric mean titer (GMT) according to PERKINS (1958).

Statistical analysis. The program Statgraphics ${ }^{\circledR}$ Centurion $X V$ version 15.1 was used to perform statistical analysis. The data were submitted to analysis of variance and statistical difference was verified by simple regression $(\mathrm{P}<0.05)$.

\section{RESULTS}

Group A consisted of 440 serum samples of dogs with history of vaccination, as ascertained by interviews with the owners and/or presentation of the vaccination card. From these, 310 samples $(70.6 \%)$ presented neutralizing antibodies to RABV in titers $\geq 0.5 \mathrm{IU} \mathrm{mL} \mathrm{mL}^{-1}$. The other 129 samples $(29.4 \%)$ were negative or harbored antibody titers $<0.5 \mathrm{IU} \mathrm{mL}^{-1}$ (one sample was toxic for cells). Among the 310 samples with antibody titers $\geq 0.5 \mathrm{IU} \mathrm{mL} \mathrm{mL}^{-1}$, the titers ranged from 0.5 to $\geq 16 \mathrm{IU} \mathrm{mL}^{-1}$. Figure $1 \mathrm{~A}$ presents the frequency and distribution of the respective neutralizing antibodies titers against RABV in the analyzed samples. The titer was $0.5 \mathrm{IU} \mathrm{mL}^{-1}$ in $6.1 \%$ samples; $7.5 \%$ had a titer of $1 \mathrm{IU} \mathrm{mL}^{-1}, 12.1 \%$ had a titer of $2 \mathrm{IU} \mathrm{mL}^{-1}, 15.9 \%$ presented a titer of $4 \mathrm{IU}$ $\mathrm{mL}^{-1}, 18 \%$ presented a titer of $8 \mathrm{IU} \mathrm{mL}^{-1}$ and $10.9 \%$ presented a titer of $16 \mathrm{IU} \mathrm{mL}^{-1}$ or higher (Figure 1A). The GMT of the reagents was $3.8 \mathrm{IU} \mathrm{mL}^{-1}$.

Among dogs harboring antibody titers $\geq 0.5 \mathrm{IU} \mathrm{mL} \mathrm{mL}^{-1}, 77.4 \%$ had a history of more than one dose of rabies vaccine and the mean number of prior vaccinations in these animals was 4.3 times. A relationship between the number of vaccinations and the titer of antibodies could be observed in these animals (simple regression $[\mathrm{P}<0.05]$ ).

The mean number of vaccinations was 2.74 times in the 129 animals that were seronegative or harbored antibody titers $<0.5 \mathrm{IU} \mathrm{mL}^{-1}$. Among these dogs, $42.6 \%(55 / 129)$ had received only one vaccine dose and the other $57.4 \%(74 / 129)$ received two or more doses. Among these animals, $64.7 \%$ received the last rabies shot two years ago. In contrast, $92.9 \%$ of the animals harboring antibody titers $\geq 0.5 \mathrm{IU} \mathrm{mL}^{-1}$ had been vaccinated in the previous year.

Group B consisted of dogs submitted to the HVU/UFSM for clinical and/or surgical procedures with unknown historic of rabies vaccination. Among these animals, 42.3\% (127/300) presented antibody titers $\geq 0.5 \mathrm{IU} \mathrm{mL}^{-1}$, indicating adequate protection, whereas $57.7 \%$ (173/300) had no detectable neutralizing antibodies against RABV (Figure 1B).

\section{DISCUSSION}

Massive vaccination of dogs and cats has contributed significantly for the drastic reduction of urban rabies in several Latin American countries, including Brazil (WIDDOWSON et al., 2002). In Brazil, official immunization programs were successful in reducing the incidence of the disease, leading to virtual eradication of rabies in most states. Unfortunately, these programs were eventually discontinued, being gradually replaced by voluntary and/or unofficial campaigns/initiatives of immunization (ALBAS et al., 2013). These initiatives are generally isolated, uncoordinated and are not subjected to official/governmental control. Although the number of rabies cases has been reduced, sporadic cases of canine, feline and human rabies have been occasionally reported in some Brazilian states/cities (CRMV-RS, 2014; SILVA et al., 2015).

In RS, urban rabies is considered virtually eradicated. Only two cases, probably transmitted from bats to dogs/cats (since involved the bat RABV lineage), have been reported in the last two decades, with no transmission within these species (CEVS, 2013). However, rabies in livestock has reached unprecedented levels in the last years, with official estimates exceeding 50,000 bovine deaths. Hence, the massive RABV circulation in wild/rural areas has led to the concern of its possible transmission to urban dogs and cats. In this sense, maintaining vaccine coverage in urban dog and cat populations would be recommended as to minimize the risk of introduction and transmission of RABV virus in cities. 
A





Figure 1 - Distribution of neutralizing antibodies titers against rabies virus. International units per milliliter (IU mL $\left.\mathrm{m}^{-1}\right)$. A - Samples of canine serum group A ( $\mathrm{n}=439)$, with a history of anti-rabies vaccination of at least one dose in the last two years. B Samples of canine serum group B $(n=300)$, with no known history of rabies vaccination.

Serological analysis of dogs with history of rabies vaccination (group $\mathrm{A}=440$ samples) showed that $70.6 \%$ (310) harbored anti-RABV antibody titers compatible with protection (WHO, 2013). Moreover, approximately $90 \%$ of these dogs had titers at least twice as high as $0.5 \mathrm{IU} \mathrm{mL}^{-1}$ (Figure 1A). Conversely, 129 samples $(29.3 \%)$ were negative or contained antibodies titers below the threshold level recommended by the WHO. These data is concerning considering the vaccination status of the animals - all have been vaccinated within the last two years - and indicated failure in the vaccination strategy and/or in vaccine quality.

From the 129 dogs harboring nonprotective or undetectable antibodies levels, 55 (42.6\%) had received a single vaccine dose in the past. The manufacturer's protocols of rabies vaccines licensed in Brazil recommend a single vaccine dose and a booster 12 months later. These protocols disagree from most protocols for inactivated, adjuvanted viral vaccines, which usually recommend an initial vaccination and a booster 30 days later to complete the immune stimulation (FLORES - verbal report). Thus, it appears that part of the animals harboring low antibody titers would not have been adequately vaccinated. In this sense, our data reinforce the need of a booster vaccination soon after the first vaccine dose ( $\sim 30$ days apart) for the induction of adequate antibodies levels.

A few studies have investigated the serological response of dogs to RABV vaccines in Brazil. Nonetheless, these studies employed different methodologies, varied experimental designs, different animal populations, varied sampling times/intervals, diverse number of doses and vaccination intervals, etc. These differences/discrepancies preclude a more detailed and precise comparison of the results. RAMANNA et al. (2007) verified that only $56 \%$ of dogs receiving a single vaccine dose developed adequate antibodies levels. PÁEZ et al. (2011) observed that $48 \%$ of the animals not receiving an annual booster vaccination did not harbor adequate serological response to RABV. Examining 432 serum samples of young and adult dogs that received a single dose of anti-RABV vaccine, SILVA et al. (2014) reported that $21.76 \%$ did not present adequate antibodies levels, being $67.02 \%$ from puppies. The authors concluded that puppies should receive a second vaccine dose as a complement of primevaccination to increase the antibodies titers. Similar results were observed in other studies (ALMEIDA et al., 1997; SEGHAIER et al., 1999; SILVA et al., 2009), reinforcing the need for complementation of primary vaccination in those animals receiving the first anti-RABV vaccine.

Failures in the immunization to RABV were also reported by ALBAS et al. (2013) when analyzing the serological response in 834 vaccinated dogs and cats in southeastern Brazil. Only 52.1\% of the vaccinated dogs had detectable neutralizing antibodies titers. In the studies mentioned above, the age or primary vaccination and lack of a shortinterval booster (or a complement of primary vaccination) appear as the major problems leading 
to vaccination failure. Reinforcing the importance of complementation of primary vaccination, BABBONI et al. (2014) demonstrated that $99 \%$ of 576 primo vaccinated dogs receiving a booster 30 days later harbored adequate antibody levels when examined a month later.

Most campaigns of vaccination of dogs and cats against rabies in Brazil - including that carried out annually in Santa Maria/RS - employ vaccines containing inactivated RABV amplified in BHK-21 cells and aluminum hydroxide as adjuvant. Vaccine quality, dose, age of primary vaccination, nutritional status, presence of concomitant infections, in addition to the individual immunological capacity may interfere with the indices of vaccine failure (SEGHAIER et al., 1999; ALMEIDA et al., 1997; MORTERS et al., 2014). As these factors were not evaluated in the present study, it is not possible to attribute to any of them the observed unresponsiveness to vaccination in many animals.

Testing the samples of dogs from group $\mathrm{B}$ (no known history of anti-RABV vaccination) revealed that $42.3 \%(127 / 300)$ had titers equal to or higher than $0.5 \mathrm{IU} \mathrm{mL}^{-1}$, while $57.7 \%(173 / 300)$ had no antibodies in titers considered to be protective (Figure 1B). These animals represented a convenience sample and, as such, should not be considered representative of the canine population of Santa Maria. In fact, these values are likely overestimated comparing to the real vaccine coverage in the total canine population, since they probably represent dogs from owners with socioeconomical above the population average. For these reasons, the real frequency of dogs with protective antibody titers to RABV in Santa Maria is likely lower than the $42.3 \%$ detected in this study.

The actual size of the dog populations is generally underestimated due to the difficulty of counting stray dogs and, as a result, the vaccine coverage is frequently overestimated (SUZUKI et al., 2008). The ratio between human and dog varies according to the demographic, behavioral and spatial characteristics of the dogs and demographic and socioeconomic characteristics of the human population (WHO, 2013). NUNES et al. (1997) surveyed a city in the interior of São Paulo State and estimated that the population of dogs corresponds to $28 \%$ of the human populations. ALVES et al. (2005), also in São Paulo State, reported 25\% (one dog for every four inhabitants). MASCARENHAS et al. (2009) in a municipality in the northeast of the Bahia state, estimated $15 \%$ the dog population in relation to the number of inhabitants. Santa Maria has approximately 300,000 inhabitants and the actual size of the canine population is unknown. Considering an average estimate of $20 \%$ of the human population, the total dog population would reach approximately 60,000 dogs. Non-official annual vaccination campaign covers between 13,000 and 18,000 animals annually (FLORES - verbal report). The number of animals immunized in private clinics and pet shops is unlikely to reach 5,000 dogs. Thus, even considering an optimistic scenario, only approximately $30 \%$ of the dog population has been vaccinated every year.

According to the WHO (2013), vaccination coverage of $70 \%$ of the canine population in nonendemic areas is enough in preventing transmission of the disease. Although, the urban area of Santa Maria is considered free of rabies, cases in cattle, horses and sheep have been reported in nearby rural communities, demonstrating the circulation of RABV. Thus, considering the potential risk of introduction of the virus from nearby rural areas, our data indicated that the vaccine coverage in dogs in Santa Maria may not be sufficient to prevent an eventual introduction and transmission of the virus to unprotected dogs.

\section{CONCLUSION}

Serological testing demonstrated that approximately $30 \%$ of dogs with recent history of vaccination against rabies in Santa Maria/RS do not contain neutralizing antibodies against RABV in adequate levels. The introduction of a booster vaccination soon after the initial vaccine dose in puppies may be necessary to raise the antibody levels and vaccine coverage. Serological testing of dogs with unknown historic of vaccination revealed that vaccine coverage in the dog population is probably below the levels recommended by the WHO. In conclusion, the strategy of immunization must be reviewed and vaccine coverage must be expanded as to provide adequate protection to the dog population against a potential introduction of RABV.

\section{VERBAL REPORT}

FLORES, E.F. Setor de Virologia, Departamento de Medicina Veterinária Preventiva, Centro de Ciências Rurais, Universidade Federal de Santa Maria. Av. Roraima, 1000. Camobi, Santa Maria - RS.97105-900. E-mail: eduardofurtadoflores@gmail.com.

\section{BIOETHICS AND BIOSSECURITY COMMITTEE APPROVAL}

All procedures employed in the study have been approved by an Institutional Ethical Committee (Comissão de Ética no Uso de Animais (CEUA), Universidade Federal de Santa Maria (UFSM), protocol 080/2014). 


\section{ACKNOWLEDGEMENTS}

The authors thank the Conselho Nacional de Desenvolvimento Científico e Tecnológico (CNPq) for the scholarships. Karina G. Fernandes received masters scholarship, Mathias M. received doctoral scholarship (process 142148/2011-3) and Eduardo F. Flores (process 301414/2010-6) and Rudi Weiblen (process 304153/2014-1) were supported by research productivity fellowship.

\section{REFERENCES}

ALBAS, A. et al. Humoral immune response in dogs and cats vaccinated against rabies in southeastern Brazil. Journal of Venomous Animals and Toxins including Tropical Diseases, v.19, n.17, p.1-3, 2013. Available from: <http://www.jvat.org/ content/19/1/17>. Accessed: May 28, 2016. doi: 10.1186/16789199-19-17.

ALMEIDA, M.F. et al. Humoral immune response of dogs to the inactivated suckling mouse brain vaccine utilized in antirabies campaigns in Brazil. Revista Saúde Pública, v.31, n.5, p.502-507, 1997. Available from: <http://www.scielo.br/scielo. php? script $=$ sci_arttext\&pid $=$ S0034-89101997000600009\&lng =en \&nrm=iso $>$. Accessed: Feb. 20, 2017. doi: 10.1590/S003489101997000600009 .

ALVES, M.C.G.P. et al. Estimation of the dog and cat population in the State of São Paulo. Revista de Saúde Pública, v.39, n.6, p.891-897, 2005. Available from: <http://www.scielo.br/pdf/rsp/ v39n6/26982.pdf>. Accessed: Feb. 20, 2017.

ARELLANO-SOTA, C. Vampire bat-transmitted rabies in cattle. Reviews of Infectious Diseases, v.10, p.707-709, 1988. Available from: $<$ https://academic.oup.com/cid/article-abstract/10/ Supplement_4/S707/290044/Vampire-Bat-Transmitted-Rabiesin-Cattle>. Accessed: Oct. 05, 2016. doi: 10.1093/clinids/10. Supplement_4.S707.

BABBONI, S.D. et al. Kinetics of rabies antibodies as a strategy for canine active immunization. Journal of Venomous Animals and Toxins including Tropical Diseases, v.20, p.37, 2014. Available from: <http://www.jvat.org/content/20/1/37>. Accessed: Mar. 15, 2016. doi: 10.1186/1678-9199-20-37.

CABRAL, C.C. et al. Circulation of the rabies virus in nonhematophagous bats in the City of Rio de Janeiro, Brazil, during 2001-2010. Revista da Sociedade Brasileira de Medicina Tropical, v.45, n.2, p.255-256, 2012. Available from: <http:// www.scielo.br/pdf/rsbmt/v45n2/v45n2a08.pdf $>$. Accessed: May 21, 2016. doi: 10.1590/S0037-86822012000200008.

CEVS (CENTRO ESTADUAL DE VIGILÂNCIA EM SAÚDE do Rio Grande do Sul). Boletim Epidemiológico, v.5, n.1, p.1-16, 2013. Available:<http://wp.ufpel.edu.br/ccz/files/2016/03/Raivano-Rio-Grande-do-Sul.pdf>. Accessed: Oct. 20, 2016.

CRMV-RS. Rio Grande do Sul volta a registrar casos de raiva felina e canina. Revista Veterinária e Zootecnia, n.78, p.10, 2014. Available from: <http://www.crmvrs.gov.br/jornal/78.pdf > Accessed: May 07, 2016.

ICTV (INTERNATIONAL committee ON TAXONOMY OF VIRUSES), 2014. Available from: <http://www.ictvonline.org/ virusTaxonomy.asp/>. Accessed: May 05, 2016.
MASCARENHAS, M.T.V.L. et al. Geotecnologias na análise da população canina para o controle da raiva, considerando fatores socioeconômicos e demográficos. Município de Lauro de Freitas (BA) 1999-2004. Revista Baiana de Saúde Pública, v.33, n.3, p.323, 2009. Available from: <http://inseer.ibict.br/rbsp/index.php/ rbsp/article/viewFile/216/pdf_47>. Accessed: Feb. 20, 2017.

MORTERS, M.K. et al. Achieving populationlevel immunity torabies in free-roaming dogs in Africa and Asia. PLoS Neglected Tropical Disease, v.8, n.11, e3169, 2014. Available from: $<$ http://journals.plos.org/plosntds/article?id=10.1371/journal. pntd.0003160>. Accessed: Feb. 20, 2017. doi: 10.1371/journal. pntd.0003160.

NUNES, C.M. et al. Evaluation of dog population in an urban area of Southeastern Brazil. Revista de Saúde Publica, v.31, n.3, p.308-309, 1997. Available from: <http://repositorio. unesp.br/bitstream/handle/11449/65120/2-s2.0-1842639498. pdf? sequence $=1 \&$ is Allowed $=\mathrm{y}>$. Accessed: Feb. 20, 2017. doi: 10.1590/S0034-89101997000300013.

OIE (ORGANIZATION OF INTERNATIONAL ANIMAL HEALTH), 2016. Available from: <http://www.oie.int/en/ animal-health-in-the-world/rabies-portal/about-rabies/>. Accessed: Oct. 17, 2016.

PÁEZ, A. et al. Evaluation of the seroconversion as a response to rabies vaccination in dogs, Valle del Cauca, Colombia, 2009. Biomédica, v.31, n.4, p.474-484, 2011. Available from: <http://www.scielo.org.co/ pdf/bio/v31n4/v31n4a02.pdf $>$. Accessed: Apr. 25, 2016.

PERKINS, F.T. A ready reckoner for the calculation of geometric mean antibody titres. Journal General Microbiology, v.19, p.540541, 1958. Available from: <http://www.microbiologyresearch. org/docserver/fulltext/micro/19/3/mic-19-3-540.pdf?expires=1476 752917\&id=id\&accname $=$ guest \& checksum $=91240$ AC2365EF3A E22A99426A30C14E3>. Accessed: Oct. 15, 2016.

RAMANNA, B.C. et al. A study on the seroconversion in dogs vaccinated with cell culture rabies vaccine. Journal of Communicable Diseases, v.39, p.165-170, 2007. Available from: $<$ http://www.ncbi.nlm.nih.gov/pubmed/18697580> $\quad$ Accessed: Apr. 16, 2016.

RHODES, C.J. et al. Rabies in Zimbabwe: reservoir dogs and the implications for disease control. Philosophical Transactions of the Royal Society of London, v.353, p.999-1010, 1998. Available from: <http://rstb.royalsocietypublishing.org/content/353/1371/999. short>. Accessed: Oct. 12, 2016. doi: 10.1098/rstb.1998.0263.

SEAPA. Assessoria de Imprensa, Secretaria daAgricultura Pecuária e Agronegócio. Notícias. Porto Alegre, dez. 2016. Available from: $<$ http://www.agricultura.rs.gov.br/upload/arquivos/201612/02110534see-relatorio-raiva-bovina-v-3.pdf>. Accessed: Apr. 22, 2017.

SVS (SECRETARIA DA VIGILÂNCIA EM SAÚDE). Ministério da Saúde. Mapas. Raiva. 2016. Available from: <http://portalsaude. saude.gov.br/index.php/o-ministerio/principal/leia-mais-oministerio/752-secretaria-svs/vigilancia-de-a-a-z/raiva/11431situacao-epidemiologica-dados>. Accessed: May 08, 2016.

SEGHAIER, C. et al. Rabies mass vaccination campaigns in Tunisia: are vaccinated dogs correctly immunized? American Society of Tropical Medicine and Hygiene, v.66, n.6, p.879-884, 1999. Available from: <http://www.ajtmh.org/content/61/6/879. full.pdf>. Accessed: Jan. 22, 2016. 
SILVA, M.L.C.R. et al. Isolation of rabies virus from the parotid salivary glands of foxes (Pseudalopex vetulus) from Paraíba State, Northeastern Brazil. Brazilian Journal of Microbiology, v.40, n.3, p.446-449, 2009. Available from: <http://www.scielo.br/pdf/ bjm/v40n3/v40n3a04.pdf>. Accessed: May 15, 2016. doi: 10.1590/ S1517-83822009000300004.

SILVA, V.A. et al. Humoral immune response of domestic dogs that received a single dose of rabies vaccine. Revista de Educação Continuada em Medicina Veterinária e Zootecnia, v.12, n.1, p.20-25, 2014. Available from: <http://189.126.110.61/recmvz/ article/view/23105/23957>. Accessed: Mar. 10, 2016.

SILVA, W.A. et al. Canine rabies in Corumbá town, Mato Grosso do Sul state, Brazil, 2015: case report. Acta Veterinária Brasileira, v.9, n.4, p.386-390, 2015. Available from: <https:// www.alice.cnptia.embrapa.br/alice/bitstream/doc/1035300/1/ artigoraivacorumba.pdf $>$. Accessed: May 20, 2016.

SMITH, J.S. et al. A rapid reproducible test for determining rabies neutralizing antibody. Bulletin of the World Health Organization, v.48, n.5, p.535-541, 1973. Available from: <https://www.ncbi nlm.nih.gov/pmc/articles/PMC2482941/pdf/bullwho00178-0027. pdf $>$. Accessed: Oct. 30, 2016.
SUZUKI, K. et al. Rabies - vaccination coverage and profiles of the owned - dog population in Santa Cruz de la Sierra, Bolivia. Zoonoses and Public Health, v.55, n.4, p.177-183. Available from: <http:// onlinelibrary.wiley.com/doi/10.1111/j.1863-2378.2008.01114.x/full>. Accessed: Feb. 20, 2017. doi: 10.1111/j.1863-2378.2008.01114.x.

WAGNER, R.R. et al. Classification of rhabdovirus proteins: a proposal. Journal of Virology, v.10, p. 1228-1230, 1972. Available from: <http://www.ncbi.nlm.nih.gov/pmc/articles/PMC356605/>. Accessed: Apr. 30, 2016.

WHO (WORLD HEALTH ORGANIZATION). WHO Expert Consultation on Rabies:secondreport,2013.Availablefrom: $<$ http:// apps.who.int/iris/bitstream/10665/85346/1/9789240690943_eng. pdf>. Accessed: Oct. 20, 2016.

WIDDOWSON M.A. et al. Epidemiology of urban canine rabies, Santa Cruz, Bolivia, 1972-1997. Emerging Infectious Diseases, v.8, n.5, p.458-461, 2002. Available from: <http://www.ncbi.nlm. nih.gov/pubmed/11996678>. Accessed: May 28, 2016. doi: 10.3201/ eid0805.010302. 